\title{
Decolorization of Textile Effluent by Immobilized Aspergillus terreus
}

\author{
Engade K.B ${ }^{1 *}$ and Gupta S.G ${ }^{2}$ \\ ${ }^{1}$ Govt.Institute of Science, Dept.Of Microbiology, Nipatniranjan Nagar, Aurangabad - 431004, India \\ ${ }^{2}$ Director SIAC, Near CST, Mumbai, Maharashtra, India
}

\begin{abstract}
The present investigation envelopes the uptake of dyes from textile effluent by a fungal culture Aspergillus terreus immobilized in various matrices.

Results confirmed that the percent adsorption of dyes from textile effluent (1:4) diluted, by Aspergillus terreus immobilized in Loofa sponge after 48 hours was $91.1 \%$ with 8 loofa pieces.

The percent adsorption of dyes from undiluted textile effluent by 8 pieces of loofa sponge immobilized with A.terreus was $50.5 \%$ in 48 hours. When pH of diluted effluent was adjusted to 7.0 percent adsorption of dyes by 8 pieces of loofa sponge immobilized with A.terreus was $98.7 \%$. Percent uptake of dyes at $\mathrm{pH} 7$ by coconut fibre and groundnut shell matrix immobilized with A.terreus in 48 hrs was $31.2 \%$ and $55 \%$ respectively and at $\mathrm{pH} 10$ it was $27.4 \%$ and $37.8 \%$.
\end{abstract}

Keywords: Textile effluent; adsorption; Loofa sponge; Immobilized

\section{Introduction}

Synthetic dyes are widely used in a number of industrial processes, such as textile industries, paper printing, and photography [1]. Dyes usually have synthetic origins and complex aromatic molecular structures [2]. Dye wastewaters discharged from textile dyestuff industries have to be treated due to their impact on water bodies, and growing public concern over their toxicity and carcinogenicity in particular.

Several strategies are currently available to remove color from the industrial effluent. These include physical processes such as membrane technologies, chemical processes such as ozonation, physicochemical methods, adsorption, chemical precipitation, flocculation, photolysis, and ion pair extraction and biological processes such as biodegradation and bioadsorption [3]. The available methods require considerable start-up costs and cannot meet increasingly stringent effluent colour standards. Many different and complicated molecular structures of dyes make dye wastewaters difficult to be treated by conventional biological and physico-chemical processes. Therefore, innovative treatment methods need to be investigated [4].

Use of immobilized microbial cells in the field of wastewater treatment has been found to be useful because of the advantages which include long retention time of biomass in the system, ease of use in a continuous reactor and their ability for scale up. Search for alternative carrier for immobilization had shown the loofa sponge (Luffa cylindrica) as a suitable matrix for immobilization of various microorganisms like Candida brassica, Aspergillus niger and Lactococcus lactis [5-9].

In the present investigations textile effluent from a local silk mill was obtained and its decolorization studied using immobilized Aspergillus terreus. Three different matrices for immobilization of Aspergillus terreus were tried namely, loofa sponge (Luffa cylindrica), coconut fibre and groundnut shells.

Aurangabad is a historical city famous for its Himroo textile. There are many textile mills at the outskirts of the city. The aim of this study was to design an effluent treatment technology which will be economically feasible for these small scale industries.

\section{Materials and Methods}

\section{Fungal culture}

Aspergillus terreus, isolated on Czapex dox agar plates from textile effluent and maintained on Potato Dextrose Agar slants.

Textile Effluent: Local textile effluent ( $\lambda$ max $650 \mathrm{~nm})$.

\section{Matrix for immobilization}

Loofa sponge, groundnut shell and coconut fibre Loofa sponge matrix for fungal immobilization was prepared by cutting dry loofa sponge into circular pieces, washed with distilled water to remove impurities and dried in oven at $105^{\circ} \mathrm{C}$. The dried matrices were then cut in small pieces of size $(1.5 \times 2 \mathrm{~cm})$ weighing approximately $0.1 \mathrm{gm}$. Loofa sponge pieces were placed in Potato Dextrose broth and sterilized at $121^{\circ} \mathrm{C}$ at $15 p s i$ for 15 minutes. The medium was cooled and then inoculated with $1 \mathrm{ml}$ of suspension containing $10^{6}$ spores of Aspergillus terreus and kept for incubation on shaker (100 $\mathrm{rpm}$ ) at $30^{\circ} \mathrm{C}$ for 6 days during which heavy fungal growth was found entrapped in the loofa matrix. Immobilized material was removed from the flasks and tried for dye adsorption studies.

Groundnut shell and coconut fibre were cut into small pieces of about $0.2 \mathrm{~mm}$ and were washed with distilled water in order to remove impurities and dried in an oven. These materials were then added to potato dextrose broth and autoclaved at $121^{\circ} \mathrm{C}$ for $15 \mathrm{~min}$. After sterilization flasks were cooled and were inoculated with $1 \mathrm{ml}$ of suspension containing $10^{6}$ spores of Aspergillus terreus and kept

*Corresponding author: Engade, K.B, Govt.Institute of Science, Department of Microbiology, Nipatniranjan, Nagar, Aurangabad - 431004, India, Tel: 9967051206 E-mail: drkrantikurwade3@gmail.com

Received August 05, 2010; Accepted September 27, 2010; Published Septembe 27, 2010

Citation: Engade KB, Gupta SG (2010) Decolorization of Textile Effluent by Immobilized Aspergillus terreus. J Pet Environ Biotechnol 1:101. doi:10.4172/21577463.1000101

Copyright: (C) 2010 Engade KB, et al. This is an open-access article distributed under the terms of the Creative Commons Attribution License, which permits unrestricted use, distribution, and reproduction in any medium, provided the original author and source are credited. 
Citation: Engade KB, Gupta SG (2010) Decolorization of Textile Effluent by Immobilized Aspergillus terreus. J Pet Environ Biotechnol 1:101. doi:10.4172/2157-7463.1000101

Page 2 of 3

\begin{tabular}{|c|c|c|c|c|}
\hline & \multicolumn{4}{|c|}{ Textile effluent(1:4)diluted } \\
(pH 8.5)
\end{tabular}

Average of 3 readings

Table 1: Adsorption of dyes from diluted (1:4) textile effluent by Aspergillus terreus immobilized in Loofa sponge.

\begin{tabular}{|c|c|c|c|c|}
\hline \multirow[b]{2}{*}{$\begin{array}{l}\text { No. of } \\
\text { loofa }\end{array}$} & \multicolumn{4}{|c|}{$\begin{array}{c}\text { Textile mill effluent } \\
(\mathrm{pH} \mathrm{10.5)}\end{array}$} \\
\hline & $\begin{array}{l}\text { OD after } 24 \mathrm{hrs} \\
(650 \mathrm{~nm})\end{array}$ & $\%$ Ads. & $\begin{array}{l}\text { OD after } \\
48 \mathrm{hrs} \\
(650 \mathrm{~nm})\end{array}$ & $\%$ Ads. \\
\hline Control & 2.076 & 00 & 2.076 & 00 \\
\hline 2 & 1.927 & 7.1 & 1.885 & 9.2 \\
\hline 3 & 1.819 & 12.3 & 1.741 & 16.1 \\
\hline 4 & 1.801 & 13.2 & 1.713 & 17.4 \\
\hline 5 & 1.779 & 14.3 & 1.282 & 38.2 \\
\hline 6 & 1.286 & 38.0 & 1.094 & 47.3 \\
\hline 8 & 1.196 & 42.3 & 1.041 & 50.5 \\
\hline
\end{tabular}

Average of 3 readings

Table 2: Adsorption of dyes from original textile effluent by Aspergillus terreus immobilized in Loofa sponge.

\begin{tabular}{|c|c|c|c|c|}
\hline \multirow{2}{*}{$\begin{array}{c}\text { No. of unimmobilized } \\
\text { loofa }\end{array}$} & \multicolumn{4}{|c|}{$\begin{array}{c}\text { Textile mill effluent } \\
\text { (pH 10.5) }\end{array}$} \\
\cline { 2 - 5 } & $\begin{array}{c}\text { OD after 24hrs } \\
\mathbf{( 6 5 0 n m )}\end{array}$ & \% Ads. & $\begin{array}{c}\text { OD after } \\
\mathbf{4 8} \text { hrs } \\
\mathbf{( 6 5 0 n m )}\end{array}$ & \% Ads. \\
\hline Control & 2.076 & 00 & 2.076 & 00 \\
\hline 2 & 2.053 & 1.10 & 2.049 & 1.3 \\
\hline 3 & 2.045 & 1.49 & 2.039 & 1.78 \\
\hline 4 & 2.012 & 3.08 & 1.993 & 3.99 \\
\hline 5 & 1.967 & 5.25 & 1.955 & 5.82 \\
\hline 6 & 1.935 & 6.79 & 1.920 & 7.51 \\
\hline 8 & 1.886 & 9.15 & 1.863 & 10.26 \\
\hline & & & & \\
\hline
\end{tabular}

Table 3: Adsorption of dyes from original textile effluent by Unimmobilized Loofa sponge.

for incubation on shaker. In 6 days sufficient amount of the fungal growth was found trapped in the matrix of groundnut shells and coconut fibre. Immobilized material was filtered through Whatman filter paper and used for dye adsorption studies.

\section{Decolorization process}

Flasks containing $100 \mathrm{ml}$ of diluted (1:4) textile effluent $(\mathrm{pH}$ 8.5) and flasks containing undiluted textile effluent ( $\mathrm{pH} 10.5)$ were inoculated with increase in the number of A.terreus immobilized loofa sponge pieces according to (Table 1 and Table 2) and $2.5 \mathrm{~g}$ each of A.terreus immobilized ground nut shell and coconut fibre. Uninoculated flask served as a control which gives the initial optical density of diluted and undiluted effluent. The flasks were kept on a shaker (100rpm). After $24 \mathrm{hrs}$ and $48 \mathrm{hrs}$ retention time the immobilized material was separated by filtration and the optical density values of the filtrates were determined at $650 \mathrm{~nm}$ on a UVVisible Spectrophotometer. Percent dye adsorption was determined after 24 and 48 hrs by using the formula mentioned above. Flasks containing effluent and only the matrices without immobilized fungi were also kept and dye adsorption only by the matrices was also recorded. The results are computed in (Table 1, Table 2, Table 3, Table 4 and Table 5).

\section{Results and Discussion}

As seen from the (Table 1) the percent adsorption of dyes from textile effluent (1:4) diluted, by Aspergillus terreus immobilized in Loofa sponge after 24 hours increased from $2.46 \%$ with 2 loofa pieces to $86.2 \%$ with 8 loofa pieces. And after 48 hours, the percent adsorption was $48.5 \%$ with 2 loofa pieces to $91.1 \%$ with 8 loofa pieces.

The percent adsorption of dyes from undiluted textile effluent by 8 pieces of loofa sponge immobilized with A.terreus. In 24 hrs, it was $42.3 \%$ and $50.5 \%$ in 48 hours (Table 2 ).

Percent adsorption of dye by Aspergillus terreus biomass immobilized in loofa sponge from diluted textile effluent was approximately $44 \%$ more as compared to that of original textile effluent. This could be the effect of $\mathrm{pH}$ of diluted and undiluted textile effluent and the concentration of dyes.

Data shown in Table 3 confirmed that if the $\mathrm{pH}$ of the diluted effluent is adjusted to $\mathrm{pH} 7.0$ the percent adsorption of dye by 8 pieces of loofa sponge immobilized with A.terreus was $98.7 \%$

\begin{tabular}{|c|c|c|c|c|c|}
\hline \multicolumn{2}{|c|}{ Textile effluent(pH 7) } & $\begin{array}{c}\text { OD after } \\
\text { 24hrs }\end{array}$ & \% ads. & $\begin{array}{c}\text { OD after } \\
\text { 48hrs }\end{array}$ & $\%$ ads. \\
\hline \multicolumn{2}{|c|}{ Control } & & & & \\
\hline (1:4)diluted & 0.406 & 0.005 & 98.7 & 0.005 & 98.7 \\
\hline Original & 2.076 & 0.657 & 68.3 & 0.657 & 68.3 \\
\hline
\end{tabular}

Average of 3 readings

Table 4: Adsorption of dyes from diluted effluent $(\mathrm{pH} 7)$ by Aspergillus terreus immobilized in Loofa sponge (using 8 pieces).

\begin{tabular}{|c|c|c|c|c|c|c|c|c|}
\hline & \multicolumn{6}{|c|}{ Textile effluent(1:4) diluted } \\
\cline { 2 - 9 } & \multicolumn{4}{|c|}{ pH 7 } & \multicolumn{4}{c|}{ pH 8.5 } \\
\cline { 2 - 9 } & Time & Coconut fibre & $\begin{array}{c}\text { Groundnut } \\
\text { shell }\end{array}$ & \multicolumn{2}{c|}{$\begin{array}{c}\text { Coconut } \\
\text { fibre }\end{array}$} & $\begin{array}{c}\text { Groundnut } \\
\text { shell }\end{array}$ \\
\cline { 2 - 9 } \\
\cline { 2 - 9 } & OD & \% Ads. & OD & $\begin{array}{c}\text { \% } \\
\text { Ads. }\end{array}$ & OD & $\begin{array}{c}\text { \% } \\
\text { Ads. }\end{array}$ & OD & $\begin{array}{c}\% \\
\text { Ads. }\end{array}$ \\
\hline Control & 0.425 & 00 & 0.425 & 00 & 0.431 & 00 & 0.431 & 00 \\
\hline 24 & 0.301 & 29.1 & 0.130 & 69.4 & 0.415 & 3.7 & 0.190 & 55.9 \\
\hline 48 & 0.215 & 49.4 & 0.110 & 74.1 & 0.359 & 16.7 & 0.185 & 57.0 \\
\hline
\end{tabular}

$\mathrm{pH} 8.5$ was the $\mathrm{pH}$ of the diluted effluent $(1: 4)$ and $\mathrm{pH} 7$ was adjusted using acid

Table 5: Adsorption of dyes from (1:4) diluted textile effluent \#3 by Aspergillus terreus immobilized in coconut fibre and groundnut shell.

\begin{tabular}{|c|c|c|c|c|c|c|c|c|}
\hline \multirow{4}{*}{$\begin{array}{c}\text { Time } \\
\text { (Hrs) }\end{array}$} & \multicolumn{5}{|c|}{ Original Textile effluent } \\
\cline { 2 - 9 } & $\begin{array}{c}\text { Coconut } \\
\text { fibre }\end{array}$ & Groundnut shell & \multicolumn{4}{c|}{ Coconut fibre } & \multicolumn{2}{|c|}{$\begin{array}{c}\text { Groundnut } \\
\text { shell }\end{array}$} \\
\cline { 2 - 9 } & OD & $\%$ Ads. & OD & $\%$ Ads. & OD & $\%$ Ads. & OD & $\%$ Ads. \\
\hline C & 2.081 & 00 & 2.081 & 00 & 2.075 & 00 & 2.075 & 00 \\
\hline 24 & 1.510 & 27.4 & 1.390 & 33.2 & 1.880 & 9.3 & 1.38 & 33.4 \\
\hline 48 & 1.430 & 31.2 & 0.935 & 55.0 & 1.520 & 27.4 & 1.29 & 37.8 \\
\hline
\end{tabular}

Average of 3 readings, $\mathrm{C}=$ control

Table 6: Adsorption of dyes from original textile effluent by Aspergillus terreus immobilized in coconut fibre and groundnut shell. 
Citation: Engade KB, Gupta SG (2010) Decolorization of Textile Effluent by Immobilized Aspergillus terreus. J Pet Environ Biotechnol 1:101. doi:10.4172/2157-7463.1000101

Page 3 of 3

showing an increase of 7 to $12 \%$ more dye adsorption as compared to undiluted textile effluent with $\mathrm{pH}$ 8.5. This experiment confirmed once again that at neutral $\mathrm{pH}$ dye adsorption is more either by dead biomass or immobilized biomass.

Maximum percent adsorption of dyes was obtained when 1:4 diluted textile effluent of $\mathrm{pH} 7$ was used. The neutral $\mathrm{pH}$ facilitated maximum adsorption $(98.7 \%$ ) of the dyes from the textile effluent. Whereas, undiluted textile effluent with $\mathrm{pH} 7$ showed $68.3 \%$ adsorption (Table 3).Result confirmed that as compared to $\mathrm{pH} 8.5$ and $\mathrm{pH} 10.5$ (original effluent), $\mathrm{pH} 7$ was optimum for decolorization of dye from textile effluent.

Out of these two matrices used for immobilization and decolorization groundnut shell immobilized A.terreus was found more efficient as compared to coconut fibre matrix. (Table 4)

Results confirmed that the $\mathrm{pH}$ of the effluent played a crucial role in deciding the uptake of dyes. Percent uptake of dyes at $\mathrm{pH}$ 7 by coconut fibre and groundnut shell matrix immobilized with A.terreus in 48 hrs was $31.2 \%$ and $55 \%$ respectively and at $\mathrm{pH} 10$ it was $27.4 \%$ and $37.8 \%$. Percent increase of dye adsorption by immobilized material at $\mathrm{pH} 7.0$ was between 4 to $18 \%$ as compared to $\mathrm{pH} 10.5$ of the original textile effluent.

Similarly, percent adsorption of dyes from undiluted (original) textile effluent by Aspergillus terreus immobilized on coconut fibre and groundnut shell was found to be comparatively less than that of diluted textile effluent. The values of percent adsorption for $\mathrm{pH} 7$ are higher, as compared to $\mathrm{pH} 10.5$ (original). Results are as tabulated in (Table 5).
In this experiment, Loofa sponge was found to be an effective matrix for immobilizing Aspergillus terreus, rendering almost a clear solution. As per the results depicted in (Table 3), it was found that the loofa without the immobilized fungus adsorbed a very meagre amount of dye on its surface, and it was because of the fungus that the maximum amount of dyes were adsorbed from the textile effluent.

\section{References}

1. Oxspring D, McMullan G, Smyth W, Marchant R (1996) Decolorization and metabolism of the reactive textile dye, Remazol Black B, by an immobilized microbial consortium. Biotechnol Lett 18: 527-530.

2. Banat I, Nigam P, Singh D, Marchant R (1996) Microbial decolorization of textile dye containing effluents: a review. Bioresource Technol 58: 217.

3. Grant J, Buchanan I (2000) Color removal from pulp mill effluents using immobilized horse radish peroxidase. SFM Network Project Report.

4. Fu Y, T Viraraghavan (2003) Column studies for biosorption of dyes from aqueous solutions on immobilized Aspergillus niger fungal biomass. Water SA 29: 465-472.

5. Iqbal M, Zafar S (1994) Vegetable sponge as a matrix to immobilize microorganisms a trial study for hyphal fungi, yeast and bacteria. Lett Appl Microbiol 18: 214-217.

6. Ogbonna J, Tomiyama S, Tanaka H (1994) Loofa sponge as a carrier for microbial cell immobilization. J Ferm Biotech 78: 437-442.

7. Ogbonna J, Tomiyama S, Tanaka H (1996) Development of a method for immobilization of non-flocculating cells in Loofa sponge. Process Biochemistry 31: 737-744.

8. Ogbonna J, Tomiyama S, Liu C, Tanaka H (1997) Efficient production of ethanol by cells immobilized in Loofa sponge. J Ferment and Bioengg 84: 271-274.

9. Sun Y, Li Y, Bai S, Yang H, Hu Z (1998) Stability of immobilized R. oryzae in repetitive batch production of $L(+)$ Lactic acid effects of inorganic salts. Bioprocess Engg 19: 155-157. 